\title{
Khelatisasi Ion Aluminium oleh Asam Organik Eksudat Akar Brachiaria
}

\author{
Aluminum Ion Chelation by Organic Acids of Brachiaria Root Exudates
}

\author{
B. Hafif ${ }^{*}$, S. Sabiham ${ }^{2}$, A. Iswandi ${ }^{2}$, A. Sutandi ${ }^{2}$, dan Suyamto ${ }^{3}$ \\ ${ }^{1}$ BPTP Lampung \\ ${ }^{2}$ Departemen Ilmu Tanah dan Sumberdaya Lahan Fakultas Pertanian IPB \\ ${ }^{3}$ Peneliti Puslitbang Tanaman Pangan Departemen Pertanian \\ E-mail: hafif-bariot@yahoo.co.id *Penulis untuk korespondensi
}

\begin{abstract}
Aluminum toxicity is one of the major factors inhibiting plant growth in acid soils. Brachiaria grass adapt to high Al concentration. This experiment was conducted to study exudation of low molecular weight organic acids (LMWOA) activated by Al, from Brachiaria roots and its potential in chelating Al. Three Brachiaria species, i.e. B. decumbens, B. ruziziensis and $B$. brizantha, planted in sterile sand culture and were treated with $5 \mathrm{Al}$ concentrations $(0,100,200$, 300 and $400 \mu M)$. After two-month experiment, three kinds of LMWOA, i.e, malic, citric, and oxalic acids, produced by the three Brachiaria-root exudates were measured in the sand culture. The production of malic acid was higher than that of citric and oxalic acid. Those organic acids were influenced by Al concentration; the higher Al concentration the higher organic acid content would be. The organic acids were also proved to form Al-organic compounds effectively of which $B$. decumbens and $B$. brizantha were more effective in chelating $\mathrm{Al}$ at relatively low $\mathrm{Al}$ $(100 \mu \mathrm{M})$ and at relatively high $\mathrm{Al}$ concentration $(300 \mu \mathrm{M}$ and $400 \mu \mathrm{M})$, respectively.
\end{abstract}

Key words: Aluminum, chelation, citric acid, oxalic acid, malic acid, Brachiaria

\begin{abstract}
Abstrak
Keracunan aluminium adalah salah satu faktor utama yang menghambat pertumbuhan tanaman pada tanah-tanah masam. Rumput Brachiaria beradaptasi baik terhadap konsentrasi Al tinggi. Penelitian ini dilakukan untuk mempelajari eksudasi asam-asam organik yang diaktivasi Al dari akar Brachiaria dan potensinya dalam khelatisasi aluminium. Tiga spesies Brachiaria yaitu $B$. decumbens, B. ruziziensis dan B. brizantha yang ditanam pada kultur pasir steril diperlakukan dengan 5 konsentrasi Al $(0,100,200,300$ dan $400 \mu M)$. Setelah 2 bulan penelitian, tiga jenis asam organik berat molekul rendah yaitu asam malat, asam sitrat dan asam oksalat sebagai produk dari eksudat akar ketiga spesies Brachiaria terukur di dalam kultur pasir. Asam malat terukur lebih banyak dibanding asam sitrat dan asam oksalat. Konsentrasi asam-asam organik tersebut dipengaruhi secara nyata oleh konsentrasi Al, semakin tinggi konsentrasi Al semakin banyak asam organik dihasilkan. Asam-asam organik juga terbukti efektif mengkomplek Al yakni B. ducumbens terindikasi lebih efektif mengkhelat Al pada konsentrasi Al relatif rendah $(100 \mu \mathrm{M})$ dan $B$. brizantha lebih efektif pada konsentrasi Al relatif tinggi ( 300 sampai $400 \mu \mathrm{M}$ ).
\end{abstract}

Kata kunci: Aluminium, khelatisasi, asam sitrat, asam oksalat, asam malat, Brachiaria

Diterima: 19 April 2010, disetujui: 01 September 2010

\section{Pendahuluan}

Akar mampu memodifikasi rizosfir yaitu zona tanah sempit di sekitar sistem perakaran di samping peranannya sebagai pendukung mekanik, penyerapan air dan hara untuk pertumbuhan tanaman. Akibatnya komposisi kimia tanah di rizosfir berbeda dari tanah yang bebas dari perakaran (Gobran dan Clegg, 1996). Modifikasi rizosfir dilakukan akar melalui eksudasi senyawa-senyawa organik, di antaranya senyawa-senyawa asam organik dengan berat molekul rendah atau dikenal sebagai asam organik alifatik. Senyawa-senyawa organik dieksudasi akar tanaman untuk beberapa kepentingan antara lain untuk detoksifikasi 
kation logam beracun seperti $\mathrm{Al}^{3+}$ dan untuk meningkatkan mobilitas hara berkelarutan rendah seperti $\mathrm{P}, \mathrm{Fe}$ dan $\mathrm{Zn}$ (Atmodjo, 2000; Oburger et al., 2009). Mekanisme detoksifikasi $\mathrm{Al}$ adalah $\mathrm{Al}$ pada arutan tanah ataupun kompleks jerapan mengaktivasi keluarnya asam organik dari perakaran. Selanjutnya asam organik mengkhelat $\mathrm{Al}$ dan menghambat masuknya ion Al ke sel akar (Ma, 2000; Ryan et al., 2001; Kochian et al., 2004). Hal terbaru yang diketahui dari mekanisme tersebut adalah genotip-genotip yang toleran $\mathrm{Al}$, memperlihatkan eksudasi asam organik yang diaktivasi $\mathrm{Al}$ yang lebih banyak dibandingkan genotip sensitif Al yang kadang tidak mengeksudasi asam organik sama sekali (Pineros et al., 2005). Hasil sederatan studi juga memperlihatkan korelasi yang erat antara derajat resistensi Al dengan jumlah eksudasi asam organik yang diaktivasi Al (Ryan et al., 1995a).

Keuntungan lain dari asam organik adalah merangsang aktivitas mikroba dengan mendorong simbiosis yang menguntungkan, membantu dalam respon khemotaktik, mempercepat pelapukan mineral dan menghambat pertumbuhan tanaman-tanaman kompetitor (Walker et al., 2003; Dakora dan Phillips, 2004; Oburger et al., 2009). Senyawasenyawa yang diekresikan akar ke rizosfir memuat sekitar 5-21\% dari total karbon yang difiksasi secara fotosintetik (Marschner, 1995 diacu dalam Walker et al., 2003).

Terkait dengan fungsi eksudat akar dalam detoksifiksi Al, setiap tanaman mempunyai karakter tersendiri. Untuk detoksifikasi Al tanaman kacang-kacangan mengeksudasi asam sitrat (Miyasaka et al., 1991), tanaman gandum (wheat) mengeksudasi asam malat (Delhaize et al., 1993; Zhang et al., 2003), tanaman jagung mengeksudasi lebih banyak asam sitrat dan sedikit malat (Jorge dan Arruda, 1996; Pineros et al., 2005), tanaman teh dan taro mengeksudasi lebih banyak asam oksalat (Ma dan Miyasaka, 1998; Chen et al., 2006). Asam organik yang diekskresi akar berkorelasi sangat tinggi dengan derajat toleransi tanaman terhadap Al (Ryan et al., 1995b).

Bentuk aluminium yang didetoksifikasi eksudat akar adalah $\mathrm{Al}^{3+}$, tetapi Kinraide (1997) mendapatkan $\mathrm{Al}-\mathrm{OH}\left(\mathrm{Al}-\mathrm{OH}^{2+}\right.$ dan $\left.\mathrm{Al}-\mathrm{OH}_{2}{ }^{+}\right)$ juga terindikasi beracun. Prabowo (1998) dalam penelitian pengujian derajat serapan malat terhadap $\mathrm{Al}$ menggunakan $\mathrm{Al}$ dalam bentuk gel $\mathrm{Al}(\mathrm{OH})_{3}$ karena $\mathrm{Al}$ hidroksida merupakan bagian utama dari serapan anion di dalam tanah (Davis dan Hem, 1989 diacu dalam Prabowo, 1998).

Bio-degradasi menentukan jumlah asam organik berat molekul rendah di dalam tanah (van Hees et al., 2005). Asam organik adalah satu dari sumber karbon yang paling labil di dalam tanah karena senyawa organik eksudat akar adalah sumber karbon utama mikroba tanah (Chen et al., 2006; Sudiana, 2004). Asam organik yang dikeluarkan ke larutan tanah segera diambil dan dicerna oleh komunitas mikroba (Sastro et al., 2006; Oburger et al., 2009). Waktu paruh asam organik pada tanah biasanya $<10$ jam (van Hees et al., 2002), tetapi serapan oleh permukaan mineral seperti Al oksi-hidroksida akan melindungi dari bio-degradasi, meskipun hal itu akan memperendah konsentrasinya di dalam larutan tanah (Jones et al., 2003).

Salah satu jenis tanaman yang dianggap beradaptasi baik terhadap keracunan Al pada tanah-tanah masam adalah Brachiaria (Wenzl et al., 2006). Hasil penelitian Agbenin dan Adeniyi (2005), memperlihatkan Brachiaria decumbens adalah tanaman yang menjanjikan untuk rehabilitasi tanah terdegradasi karena di bawah tanaman ini konsentrasi C-organik tanah sangat tinggi dan itu merupakan kontribusi ekskresi C labil dari akarnya. Terkait dengan hal itu perlu dipahami bagaimana tanaman Brachiaria dapat beradaptasi baik terhadap kandungan $\mathrm{Al}$ di dalam tanah (media tanam). Penelitian ini dimaksudkan untuk mempelajari eksudasi asamasam organik yang diaktivasi $\mathrm{Al}$ dari akar Brachiaria dan potensinya dalam khelatisasi aluminium (Al).

\section{Metode Penelitian}

\section{Sterilisasi Kultur Pasir}

Pasir untuk kultur tanam diambil dari pantai Pelabuhan Ratu, Sukabumi. Pertama pasir dicuci dengan air ledeng, selanjutnya dioksidasi dengan $\mathrm{H}_{2} \mathrm{O}_{2} 30 \%$ untuk menghilangkan bahan organik (Sequi dan Aringhieri, 1977) dan ditambahkan HCL 5\% untuk pembebasan dari kation terutama dari Kalsium (Van Kessel et al., 2000; Harris et al., 2001). Proses oksidasi dengan $\mathrm{H}_{2} \mathrm{O}_{2} 30 \%$ (rasio pasir : $\mathrm{H}_{2} \mathrm{O}_{2}$ adalah $1: 2$ ) 
dilakukan secara bertahap dengan terus diaduk. Setelah buih mereda, campuran pasir $\mathrm{H}_{2} \mathrm{O}_{2}$ dibiarkan selama 1 malam dan esoknya diberi $\mathrm{H}_{2} \mathrm{O}_{2}$ sampai buih menghilang. Selanjutnya kelebihan $\mathrm{H}_{2} \mathrm{O}_{2}$ dibuang, pasir diberi $\mathrm{HCl} 5 \%$ (rasio 1:1) dan dihangatkan pada hot plate selama 20 menit, sambil diaduk. Setelah itu dibilas 10 kali dengan air bebas ion. Nilai DHL dari pasir yang telah dibilas adalah $0,1 \mathrm{DS} / \mathrm{m}$ dan konsentrasi total Al 135,81 ppm, sedangkan Al dapat dipertukarkan tidak terukur. Selanjutnya Pasir disterilisasi dari mikroba dengan autoclave.

\section{Rancangan Percobaan}

Rancangan percobaan adalah Rancangan Acak Lengkap dalam susunan faktorial, diulang 3 kali (tiga ulangan). Faktor 1 spesies Brachiaria yaitu: 1) kontrol (Tanpa Brachiaria), 2) Brachiaria decumbens, 3) Brachiaria ruziziensis, 4) Brachiaria brizantha dan faktor 2 konsentrasi Al yaitu : 1) $0 \mu \mathrm{M}$, 2) $100 \mu \mathrm{M}, 3)$ $200 \mu \mathrm{M}$, 4) $300 \mu \mathrm{M}$ dan $400 \mu \mathrm{M}$. Bahan yang digunakan untuk perlakuan konsentrasi $\mathrm{Al}$ adalah $\mathrm{AlCl}_{3}$. Pemberian perlakuan $\mathrm{Al}$ dilakukan saat tanaman berumur satu minggu.

\section{Sterilisasi Tempat Penelitian}

Penelitian dilaksanakan di Rumah Kaca Faperta IPB. Di dalam rumah kaca tempat penelitian dipisahkan dengan ruangan lainnya dengan plastik transparan setinggi $2 \mathrm{~m}$. Untuk sterilisasi dinding bagian dalam plastik dan lantai tempat penelitian disemprot alkohol $70 \%$.

\section{Persemaian dan Penanaman Brachiaria}

Brachiaria sebelum ditanam pada pot penelitian, terlebih dahulu disemai selama 20 hari pada kultur pasir. Sebagai sumber hara digunakan larutan hara Hoagland. Komposisi larutan hara Hoagland adalah $5 \mathrm{mM} \mathrm{Ca}\left(\mathrm{NO}_{3}\right) 2,2$

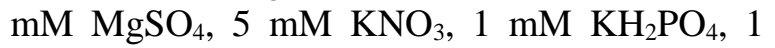
$\mathrm{mM}$ FeEDTA dan $1 \mathrm{mM}$ unsur mikro $\left(\mathrm{H}_{3} \mathrm{BO}_{3}\right.$, $\mathrm{MnCl}_{2}, \mathrm{CuCl}_{2}, \mathrm{ZnCl}_{2}$ dan $\left.\mathrm{Na}_{2} \mathrm{MoO}_{4}\right)$. Untuk persemaian Brachiaria digunakan tunas dengan bobot yang cukup seragam (2-3 g). Setelah 20 hari Brachiaria dipindah-tanamkan ke pot berisi $800 \mathrm{~g}$ kultur pasir. Untuk tahap ini dilakukan proses sterilisasi terhadap bibit yaitu dengan merendam bibit selama 3-4 menit di dalam $\mathrm{H}_{2} \mathrm{O}_{2}$ $3 \%$ dan dipindah-tanamkan ke pot pasir setelah dibilas aquades steril. Jumlah larutan Hoagland yang ditambahkan ke tiap-tiap pot tanam adalah $600 \mathrm{ml}$ dan diberikan dalam 3 tahap yaitu pada 0, 1 dan 2 minggu sesudah tanam (MST). Penyiraman tanaman dengan air bebas ion steril dilakukan setiap hari dan jumlah air yang ditambahkan sesuai dengan jumlah air yang dievapotranspirasi.

\section{Ekstraksi dan Pengukuran Konsentrasi Asam Organik dan Al-organik}

Kandungan asam organik dan Al-organik di dalam pasir dianalisis dengan metoda sentrifugasi (Angeles et al., 2006). Contoh pasir diambil dari rizosfir (kedalaman $2-5 \mathrm{~cm}$ ) di sekeliling rumpun rumput Brachiaria setelah tanaman berumur 2 bulan. Pasir dimasukan ke dalam tabung sentrifugasi sebanyak $20 \mathrm{~g}$ dicampur dengan aquades steril dengan rasio 1 : 1, kemudian disentrifugasi dengan kecepatan $4000 \mathrm{rpm}$ selama 40 menit. Sebelum disentrifugasi, $\mathrm{pH}$ campuran pasir aquades diukur (terukur $\mathrm{pH}$ 6,8-7,2). Setengah volume supernatan (volume bagian atas tabung sentrifugasi) selanjutnya dipipet dan disimpan di dalam refrigerator dengan suhu $4^{\circ} \mathrm{C}$. Setengah bagian supernatan (untuk pengukuran asam organik) disaring dengan membran $0,22 \mu \mathrm{m}$. Asam organik (asam sitrat, asam oksalat dan asam malat) diukur dengan HPLC (HighPerformance Liquid Chromatography) Varian490 dengan spesifikasi: detektor $U V$-visible, $\lambda$ $240 \mathrm{~nm}$ dan fase gerak $\mathrm{H}_{2} \mathrm{SO}_{4} 0,005 \mathrm{~N}$ dengan kecepatan aliran (flow rate) $1 \mathrm{ml} / \mathrm{menit}$. Pengukuran kadar asam organik di dalam supernatan dilakukan dalam rentang waktu $<24$ jam setelah pengambilan contoh pasir. Ion $\mathrm{Al}^{3+}$ di dalam supernatan sebagai representasi dari Alorganik diukur dengan menggunakan AAS (Atomic Absorption Spectrophotometer) merek Hitachi tipe Z 5000 pada panjang gelombang $309,3 \mathrm{~nm}$. Metode analisis standar (flame type: $\mathrm{N}_{2} \mathrm{O}-\mathrm{C}_{2} \mathrm{H}_{2}$; fuel flow 5,4 1/menit; oxidant: 13,9 1/menit dan tekanan $160 \mathrm{kPa}$ ) dengan kemampuan deteksi konsentrasi $\mathrm{Al}$ terendah 0,3 ppm.

\section{Hasil dan Pembahasan}

\section{Asam Organik Eksudat Akar Brachiaria}

Pengukuran kadar asam organik dari eksudat akar Brachiaria dilakukan setelah 
tanaman berumur 2 bulan. Hasil pengukuran disajikan pada Tabel 1.

Eksudat akar ketiga spesies Brachiaria ( $B$. decumbens, $B$. ruziziensis dan $B$. brizantha) terbukti berpotensi sebagai sumber asam organik berat molekul rendah. Jumlah asam organik yang dieksudasi akar tiap-tiap Brachiaria semakin meningkat dengan meningkatnya konsentrasi Al di dalam kultur pasir, artinya jumlah asam organik dieksudasi berkorelasi positif dengan konsentrasi $\mathrm{Al}\left(\mathrm{R}^{2}>0,95\right)$. Kandungan asam organik di dalam kultur pasir antara perlakuan konsentrasi $\mathrm{Al}$ juga berbeda nyata. Adapun nilai rata-rata tiap-tiap asam organik yang dieksudasi oleh ketiga spesies Brachiaria tidak berbeda nyata.

Hasil pengukuran asam organik tersebut sejalan dengan beberapa hasil penelitian sebelumnya. Jorge dan Arruda (1997) serta Pineros et al., (2005) melaporkan bahwa ekskresi asam sitrat dari perakaran tanaman jagung yang toleran $\mathrm{Al}$, meningkat dengan semakin meningkatnya konsentrasi Al dalam larutan hara, dan jumlah asam organik yang dieksresikan hampir 2-3 kali dibanding jumlah yang diekskresikan tanaman yang sensitif Al.

Data pada Tabel 1 juga memperlihatkan dari tiga asam organik yang terukur, asam malat dieksudasi lebih banyak. Hasil penelitian Ryan et al., (1995b); Zhang et al., (1998); Zhang et al.,(2003) memperlihatkan eksudat akar tanaman famili gramineae seperti wheat (gandum), menghasilkan lebih banyak asam malat, sedangkan eksudat akar suku kacang-kacangan lebih banyak menghasilkan asam sitrat. Uji coba penambahan asam malat ke dalam larutan hara yang ditumbuhi benih gandum yang toleran dan sensitif terhadap Al telah dilakukan oleh Delhaize et al., (1993) dan Ryan et al., (1995a). Hasil uji coba memperlihatkan asam malat mampu meningkatkan pertumbuhan benih atau secara nyata mengurangi efek toksisitas $\mathrm{Al}$ terhadap perkembangan benih dan pengaruh tersebut tergantung konsentrasi asam malat di dalam larutan hara.

Tabel 1. Konsentrasi asam organik eksudat akar tiga spesies Brachiaria umur 2 bulan di dalam kultur pasir.

\begin{tabular}{|c|c|c|c|}
\hline & \multicolumn{3}{|c|}{ Asam Organik ( $\mu \mathrm{M})$} \\
\hline & Asam Sitrat & Asam Oksalat & Asam Malat \\
\hline \multicolumn{4}{|c|}{ B. decumbens } \\
\hline Al-0 & tu & tu & tu \\
\hline Al-100 & $7,3 \mathrm{~d}$ & $39,7 \mathrm{~d}$ & $57,8 \mathrm{~d}$ \\
\hline $\mathrm{Al}-200$ & $21,0 \mathrm{c}$ & $78,1 \mathrm{c}$ & $108,8 \mathrm{c}$ \\
\hline Al-300 & $23,3 \mathrm{ab}$ & $108,1 \mathrm{~b}$ & $136,5 \mathrm{~b}$ \\
\hline $\mathrm{Al}-400$ & $30,1 \mathrm{a}$ & $143,3 \mathrm{a}$ & $211,0 \mathrm{a}$ \\
\hline Rata-rata & 16,9 & 73,8 & 102,8 \\
\hline LSD 0,05 & 8,2 & 16,9 & 19,6 \\
\hline $\mathrm{R}^{2}$ & 0,953 & 0,997 & 0,991 \\
\hline \multicolumn{4}{|c|}{ B. ruziziensis } \\
\hline$\overline{\mathrm{Al}-0}$ & tu & tu & tu \\
\hline Al-100 & $8,2 \mathrm{~d}$ & $40,4 \mathrm{~d}$ & $63,1 \mathrm{~d}$ \\
\hline $\mathrm{Al}-200$ & $18,4 \mathrm{c}$ & $70,4 \mathrm{c}$ & $98,8 \mathrm{c}$ \\
\hline Al-300 & $28,8 \mathrm{~b}$ & $117,6 \mathrm{~b}$ & $149,1 \mathrm{~b}$ \\
\hline Al-400 & $32,2 \mathrm{a}$ & $135,1 \mathrm{a}$ & $213,7 \mathrm{a}$ \\
\hline Rata-rata & 17,5 & 72,7 & 104,9 \\
\hline LSD 0,05 & 5,3 & 6,9 & 13,9 \\
\hline $\mathrm{R}^{2}$ & 0,980 & 0,985 & 0,984 \\
\hline \multicolumn{4}{|c|}{ B. brizantha } \\
\hline$\overline{\mathrm{Al}-0}$ & tu & tu & tu \\
\hline Al-100 & $6,9 \mathrm{~d}$ & $29,2 \mathrm{~d}$ & $47,9 \mathrm{~d}$ \\
\hline Al-200 & $19,1 \mathrm{c}$ & $69,4 \mathrm{c}$ & $100,3 \mathrm{c}$ \\
\hline Al-300 & $27,7 \mathrm{ab}$ & $113,2 \mathrm{~b}$ & $153,3 \mathrm{~b}$ \\
\hline Al-400 & 36,3 a & $153,9 \mathrm{a}$ & $203,4 \mathrm{a}$ \\
\hline Rata-rata & 18,0 & 73,1 & 101,0 \\
\hline LSD 0,05 & 9,8 & 18,7 & 27,0 \\
\hline $\mathrm{R}^{2}$ & 0,997 & 0,998 & 0,999 \\
\hline
\end{tabular}

Keterangan: Angka pada kolom yang sama diikuti oleh huruf yang sama tidak berbeda nyata pada taraf 5\% menurut LSD, tu= tidak terukur, $\mathrm{R}^{2}=$ kofisien korelasi. 


\section{Khelatisasi $\mathbf{A l}^{3+}$}

Data Al-organik terukur pada kultur pasir di bawah masing-masing perlakuan disajikan pada Tabel 2. Data mengindikasikan bahwa asam organik eksudat akar rumput Brachiaria efektif dalam mengkhelat Al. Hal ini terlihat dari adanya perbedaan nilai konsentrasi $\mathrm{Al}$ terukur pada sampel kultur pasir dari pot yang ditanami Brachiaria dengan yang tidak ditanami. Pada pot perlakuan penanaman Brachiaria, nilai rata-rata Al-organik terukur di dalam kultur pasir yang diperlakukan dengan berbagai konsentrasi $\mathrm{Al}$ di bawah $B$. decumbens, B. ruziziensis dan $B$. brizantha masing-masing adalah 60,5, 71,4 dan $59,1 \mu \mathrm{M}$. Nilai rata-rata Al-organik terukur di dalam pasir dengan perlakuan konsentrasi $\mathrm{Al}$ yang sama tetapi tanpa penanaman Brachiaria, adalah 3,95 $\mu \mathrm{M}$. Keadaan ini mengindikasikan bahwa hampir 95\% dari $\mathrm{Al}$ yang terukur di dalam pasir yang ditanami Brachiaria adalah senyawa komplek Al-organik.

Menurut Dynes dan Huang (1997) ketiga jenis asam organik yang terukur (asam sitrat, asam oksalat dan asam malat) mempunyai kemampuan untuk mengkomplek Al dengan senyawa komplek sitrat-Al dinilai lebih stabil dibanding oksalat-Al dan malat-Al. Kekuatan khelatisasi ini dapat dilihat dari nilai konstanta stabilitas $\left(\mathrm{K}_{\mathrm{Al}-\mathrm{L}}\right)$ sitrat-Al $\left(\log \mathrm{K}_{\mathrm{Al}-\mathrm{L}} 8,52\right)>$ oksalat-Al $\left(\log \mathrm{K}_{\mathrm{Al}-\mathrm{L}} 6,28\right)>$ malat-Al $\left(\log \mathrm{K}_{\mathrm{Al}-\mathrm{L}}\right.$ 5,80). Demikian juga Pineros et al., (2005) mengemukakan bahwa sitrat ${ }^{3-}$ (anion sitrat trikarboksilat) lebih efektif dalam khelatisasi $\mathrm{Al}$ dari pada malat ${ }^{2-}$ (anion malat dikarboksilat). Berdasarkan percobaan larutan murni mengelompokkan asam sitrat dan asam oksalat sebagai kelompok pendetoksi (detoxifier) $\mathrm{Al}$ kuat, sedangkan asam malat dikelompokkan sebagai pendetoksi Al sedang (Hue et al., 1986).

Selanjutnya pada Gambar 1 ditampilkan grafik efektivitas eksudat akar ketiga spesies Brachiaria dalam mengkhelat Al. Grafik dan data nisbah Al dikhelat memperlihatkan bahwa eksudat akar $B$. decumbens lebih efektif mengkomplek Al pada konsentrasi Al relatif rendah $(100 \mu \mathrm{M})$, dengan nilai persentase nisbah Al-organik terhadap konsentrasi Al-larut mencapai 59,6\%, sementara pada konsentrasi $\mathrm{Al}$ dalam kultur pasir relatif tinggi (200 sampai 400 $\mu \mathrm{M})$ nilai persentase nisbah tersebut terindikasi menurun. Hasil pengukuran Al-organik pada kultur pasir B. brizantha menunjukkan, nisbah Al-organik terhadap Al larut meningkat seiring meningkatnya konsentrasi Al pada kultur pasir. Pada perlakuan 100, 200, 300 dan $400 \mu \mathrm{M}$ masing-masing nilai nisbah $\mathrm{Al}$ dikhelat oleh eksudat akar B. brizantha adalah 12,8, 10,5, 31,3 dan $36,1 \%$.

B. decumbens yang efektif mengkhelat $\mathrm{Al}$ pada konsentrasi ion $\mathrm{Al}^{3+}$ lebih rendah $(100 \mu \mathrm{M})$ dinilai lebih efektif untuk detoksifikasi Al pada tanah-tanah masam. Seperti dilaporkan oleh Wenzl et al. (2003) ion $\mathrm{Al}^{3+}$ yang terdeteksi pada larutan tanah masam $\mathrm{pH}$ 5,0 dengan Al-dd 0,13 cmol (+)/kg, terukur sekitar $43 \mu \mathrm{M}$. Sedangkan Prabowo (1998) melaporkan dalam kondisi normal konsentrasi $\mathrm{Al}^{3+}$ dalam larutan tanah masam dengan $\mathrm{pH} 4,3-5,0$ adalah antara 10-50 $\mu \mathrm{M}$. Hasil pengukuran Al-dd pada tanah lahan kering masam dengan $\mathrm{pH}$ tanah 4,4-4,9 khususnya untuk daerah Lampung adalah $0,1-$ $1,26 \mathrm{cmol}(+) / \mathrm{kg}$ (sumber data dari penelitian terpisah).

\section{Pertumbuhan Brachiaria}

Secara statistik pengaruh konsentrasi $\mathrm{Al}$ yang berbeda terhadap perkembangan akar dan pertumbuhan ketiga spesies rumput Brachiaria, tidak berbeda nyata (data hasil pengamatan tidak disajikan). Fischer et al., (2001); Wenzl et al., (2003) dan Wenzl et al., (2006) melaporkan bahwa rumput Brachiaria adalah tanaman yang tumbuh baik pada tanah-tanah masam seperti Haplustox atau Paleudult dan toleran terhadap Al. Hasil penelitian secara hidroponik mengindikasikan tingkat toleransi $B$. ruziziensis terhadap keracunan ion $\mathrm{Al}^{3+}$ lebih rendah dibanding B. decumbens (Grundy et al., 2002; Wenzl et al., 2006), tetapi pada tanah masam, pertumbuhan $B$. ruziziensis baru mulai terdegradasi setelah beberapa tahun pengembangan (Rao et al., 1996; Miles et al., 2004 diacu dalam Wenzl et al., 2006). Sementara Fischer et al., (2001); Wenzl et al., (2003) mengemukakan bahwa daya adaptasi $B$. decumbens terhadap tanah masam miskin lebih baik dibandingkan dengan $B$. brizantha.

Uji Korelasi Antara Al-organik dan Asam Organik dengan Pertumbuhan Brachiaria

Uji korelasi dilakukan untuk pemahaman lebih jauh hubungan antara asam organik dan 
Al-organik dengan perkembangan akar dan pertumbuhan Brachiaria. Hasil uji korelasi menunjukan korelasi nyata antara konsentrasi Al, khelatisasi Al dan asam organik dengan perkembangan akar dan pertumbuhan Brachiaria hanya terjadi pada spesies $B$. brizantha. Hasil uji korelasi dikemukakan pada Tabel 3.

Hasil uji korelasi (Tabel 3) menunjukkan adanya korelasi nyata antara konsentrasi Al, Alorganik dan asam-asam organik pada kultur pasir dengan bobot akar, dan bobot tanaman $B$. brizantha. Demikian pula terjadi korelasi nyata antara kadar $\mathrm{Al}$ dengan Al-organik dan asamasam organik dan antara Al-organik dengan asam-asam organik. Artinya bobot akar dan tanaman $B$. brizantha terindikasi meningkat (korelasi positif) dengan peningkatan konsentrasi ion $\mathrm{Al}^{3+}$ dan aktivasi ion tersebut terhadap eksudasi asam organik dari perakaran $B$. brizantha.

Korelasi positif lain yang sangat nyata adalah antara konsentrasi Al dengan Al-organik dan asam-asam organik yang dieksudasi oleh perakaran Brachiaria. Seperti dikemukakan oleh Delhaize et al., (1993); Ma (2000); Ryan et al., (2001); Zhang et al., (2003); Kochian et al., (2004), Al merangsang atau mengaktivasi eksudasi asam-asam organik dari akar tanaman sehingga semakin tinggi cekaman Al semakin banyak asam organik dieksudasi akar untuk detoksifikasi $\mathrm{Al}$, terutama diperlihatkan oleh perakaran tanaman toleran $\mathrm{Al}$.

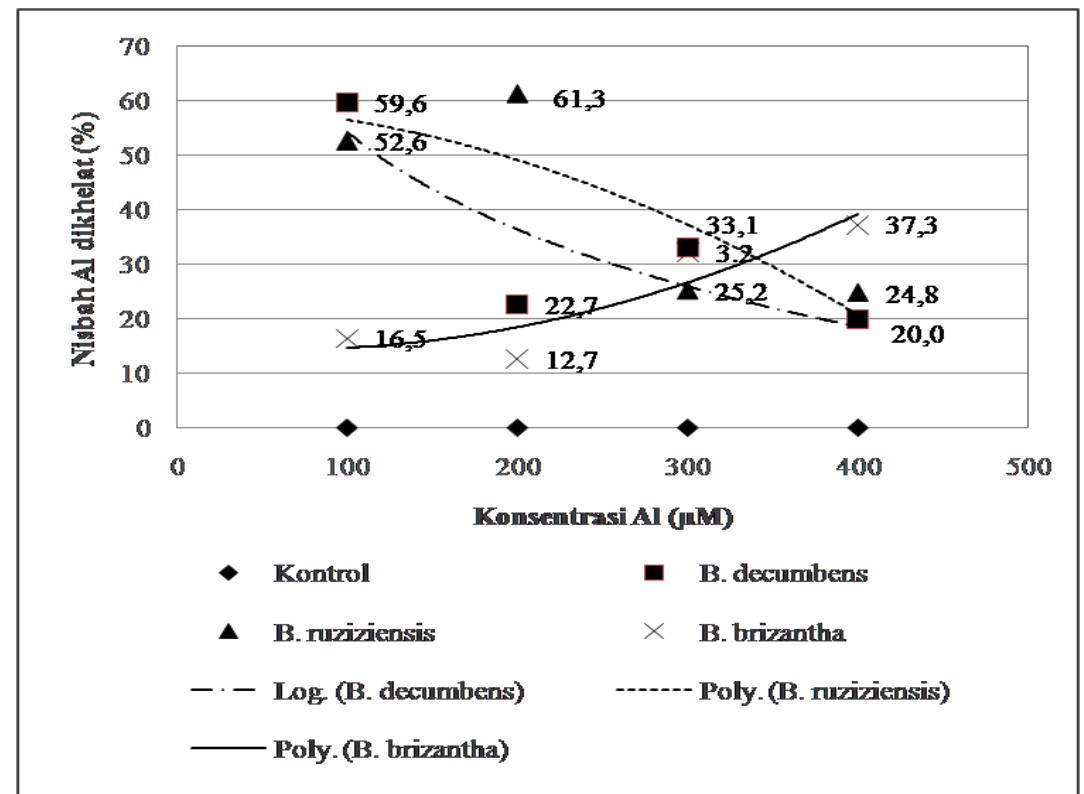

Gambar 1. Kecendrungan nisbah khelatisasi Al oleh tiap-tiap eksudat akar Brachiaria pada konsentrasi Al berbeda.

Tabel 2. Konsentrasi Al-organik di dalam kultur pasir yang diberi konsentrasi Al berbeda dan ditanami rumput $B$. decumbens, B. ruzizensi dan B. brizantha.

\begin{tabular}{lcccc}
\hline \hline \multirow{2}{*}{$\begin{array}{c}\text { Konsentrasi Al } \\
(\boldsymbol{\mu M})\end{array}$} & Tanpa Brachiaria & B. decumbens & B. ruziziensis & B. brizantha \\
\cline { 2 - 5 } & 4,07 & $3,3 \mathrm{e}$ & $6,67 \mathrm{~d}$ & $7,8 \mathrm{~d}$ \\
0 & 3,70 & $59,6 \mathrm{c}$ & $52,6 \mathrm{c}$ & $16,5 \mathrm{c}$ \\
200 & 4,07 & $45,4 \mathrm{~d}$ & $122,6 \mathrm{a}$ & $25,4 \mathrm{c}$ \\
300 & 2,96 & $99,3 \mathrm{a}$ & $75,6 \mathrm{~b}$ & $96,8 \mathrm{~b}$ \\
400 & 5,00 & $78,8 \mathrm{~b}$ & $99,1 \mathrm{~b}$ & $149,2 \mathrm{a}$ \\
Rata-rata & 3,95 & 60,5 & 71,4 & 59,1 \\
LSD 0,05 & & 10,7 & 20,6 & 11,2 \\
\hline \hline
\end{tabular}

Keterangan: Angka pada kolom yang sama diikuti oleh huruf yang sama tidak berbeda nyata pada taraf 5\% menurut LSD. 
Tabel 3. Hasil uji korelasi antara Al-organik, asam organik dengan perkembangan akar dan pertumbuhan Brachiaria brizantha.

\begin{tabular}{|c|c|c|c|c|c|c|c|c|c|c|}
\hline & Kons. Al & $\begin{array}{c}\text { Al- } \\
\text { Organik }\end{array}$ & $\begin{array}{c}\text { As. } \\
\text { Malat }\end{array}$ & $\begin{array}{c}\text { As. } \\
\text { Sitrat }\end{array}$ & $\begin{array}{c}\text { As. } \\
\text { Oksalat }\end{array}$ & $\begin{array}{l}\text { Vol. } \\
\text { Akar }\end{array}$ & $\begin{array}{l}\text { Bobot } \\
\text { Akar }\end{array}$ & $\begin{array}{c}\text { Bobot } \\
\text { Tanaman }\end{array}$ & $\begin{array}{c}\text { Jumlah } \\
\text { Daun }\end{array}$ & $\begin{array}{l}\text { Tinggi } \\
\end{array}$ \\
\hline Kons. Al & 1 & ,932 &, $996^{* * *}$ & ,983 ${ }^{* * *}$ & $995^{* *}$ & ב,528 & , $737^{* * *}$ & ,693" & ,152 & ,020 \\
\hline Al-organik & & 1 &, $930^{* *}$ &, $907^{* *}$ &, $946^{* *}$ &, 513 &, $636^{*}$ & ,615 & ,151 &,- 013 \\
\hline As. malat & & & 1 &, $981^{* *}$ &, $997^{* *}$ &, 518 &, $783^{* *}$ &, $743^{* *}$ & ,091 & ,056 \\
\hline As. sitrat & & & & 1 &, $985^{* *}$ &, 546 &, $714^{*}$ &, $666^{*}$ & ,214 &, $079^{*}$ \\
\hline As. oksalat & & & & & 1 &, 561 &, $754^{* * *}$ &, $713^{* *}$ & , 129 &, 052 \\
\hline
\end{tabular}

Keterangan: **Korelasi nyata pada taraf nyata 0,01

*Korelasi nyata pada taraf nyata 0,05

\section{Simpulan dan Saran}

\section{Simpulan}

Akar rumput Brachiaria mengeluarkan asam-asam organik seperti asam malat, asam sitrat dan asam oksalat bila mengalami cekaman Al. Dari ketiga asam organik, asam malat dieksudasi paling banyak. Asam organik berat molekul rendah tersebut efektif mengkhelat Al. Kemampuan mengkhelat Al Brachiaria decumbens berbeda dengan Brachiaria brizantha. Kemampuan Brachiaria decumbens sebagai agen untuk mengurangi keracunan $\mathrm{Al}$ paling baik.

\section{Saran}

Dalam rangka memperbaiki kwalitas tanah masam, terutama terkait dengan masalah keracunan aluminium, remidiasi secara in situ dinilai lebih efisien dan rumput Brachiaria dapat digunakan sebagai fitoremidiasi. Kebiasaan akar tanaman toleran Al mendetoksi Al dengan cara mengeksudasi asam-asam organik dapat dijadikan dasar pemikiran untuk mempelajari lebih lanjut potensi senyawa-senyawa tersebut dalam remidiasi tanah terkontaminasi logam berat.

\section{Ucapan Terima Kasih}

Terima kasih kepada Sekretariat Badan Penelitian dan Pengembangan Pertanian atas terlaksananya penelitian Kerjasama Kemitraan Penelitian Pertanian dengan Perguruan Tinggi (KKP3T). Juga kepada Indri Hapsari mahasiswa
S1 Ilmu Tanah IPB dan Staf Laboratorium Kimia dan Kesuburan Tanah Departemen Ilmu Tanah dan SDL serta Teknisi rumah kaca Faperta IPB atas bantuan yang diberikan.

\section{Daftar Pustaka}

Agbenin, J.O. dan Adeniyi, T. 2005. The Microbial Biomass Properties of a Savanna Soil under Improved Grass and Legume Pastures in Northern Nigeria. Agriculture, Ecosystems and Environment, 109: 245-254.

Angeles, O.R., Johnson, S.E. dan Buresh, R.J. 2006. Soil Solution Sampling for Organic Acids in Rice Paddy Soils. Soil Sci. Soc. Am. J., 70: 48-56.

Atmodjo, K. 2000. Penggunaan Tulang dan Kulit Nanas sebagai Pupuk Organik untuk Menumbuhkan Sawi (Brassica Juncea L.). Biota, V (2): 63-70.

Chen, Y.M., Wang, M.K., Zhuang, S.Y. dan Chiang, P.N. 2006. Chemical and Physical Properties of Rhizosphere and Bulk Soils of Three Tea Plants Cultivated in Ultisols. Geoderma, 136: 378-387.

Dakora, F.D. dan Philips, D.A. 2004. Root Exudates as Mediators of Mineral Acquisition in Lownutrient Environments. Plant and Soil J., 245 (1): $35-47$.

Delhaize, E., Ryan, P.R. dan Randall, P.J. 1993. Aluminium Tolerance in Wheat (Triticum aestivum L.) II. Aluminium-stimulated Excreation of Malic Acid from Root Apices. Plant Physiology, 103: 695-702.

Dynes, J.J. dan Huang, P.M. 1997. Influence of Organic Acid on Selenite Sorption by Poorly Ordered Aluminum Hydroxides. Soil Sci. Soc. Am. J., 6: 772-783. 
Fischer, A.J., Ramirez, H.V., Gibson, K.D. dan Pinheiro, B.D.S. 2001. Competitiveness of Semidwarf Upland Rice Cultivar Again Palisadegrass (Brachiaria brizantha) and signalgrass (Brachiaria decumbens). Agron J., 93: 967-973.

Gobran, G.R. dan Clegg, S. 1996. A Conceptual Model for Nutrient Availability in the Mineral Soil-root System. Can. J. Soil Sci., 76: 125-131.

Grundy, S.P., Jones, D.L. dan Godbold. 2002. Organic Acid Root-tip Tissue-concentration in Brachiaria decumbens and Brachiaria ruziziensis. Abstract. Developments in Plant and soil sciences 9: 506-507. http://www.springerlink. com/content/x23834/?p= 88fbf934932 94da5aa 8 aed5dbb1c5a7a\&pi=0.

Harris, D., Horwath, W.R. dan van Kessel, C. 2001. Acid Fumigation of Soils to Remove Carbonates Prior to Total Organic Carbon or Carbon-13 Isotopic Analysis. Soil Sci. Soc. Am. J., 65: 1853-1856.

Hue, N.V., Craddock, G.R. dan Adam, F. 1986. Effect of Organic Acids on Aluminium Toxicity in Subsoil. Soil Sci. Soc. Am. J., 50: 28-34.

Jones, D.L., Dennis, P.G., Owen, A.G. dan van Hees, P.A.W. 2003. Organic Acid Behaviour in Soilsmisconceptions and Knowledge Gaps. Plant and Soil, 248: 31-41.

Jorge, R.A. dan Arruda, P. 1997. Aluminium-induced Organic Acid Exudation by Roots of an Aluminium-tolerant Tropical Maize. Phytochemistry, 45 (4): 675-681.

Kinraide, T.B. 1997. Reconsidering the Rhizotoxicity of Hydroxyl, Sulphate, and Fluoride Complexes of Aluminum. J. Exp. Bot., 48: 1115-1124.

Kochian, L.V., Hoekenga, A.O. dan Piñeros, M.A. 2004. How do Plants Tolerate Acid Soils? Mechanisms of Aluminum Tolerance and Phosphorous Efficiency. Annu Rev Plant Physiol Plant Mol Biol., 55: 459-493.

Ma, J.F. 2000. Role of Organic Acids in Detoxification of Aluminum in Higher Plants. Plant Cell Physiol., 41: 383-390.

Ma, Z. dan Miyasaka, S.C. 1998. Oxalate Exudation by Taro in Response to Al Plant Physiology, 118 (3): 861-865.

Miyasaka, S.C., Buta, J.G., Howell, R.K. dan Foy, C.D. 1991. Mechanisms of Aluminum Tolerance in Snapbeans. Root Exudation of Citric Acid. Plant Physiology, 96: 737-743.

Oburger, E., Kirk, G.J.D., Wenzel, W.W., Puschenreiter, M. dan Jones, D.L. 2009. Interactive Effects of Organic Acids in The Rhizosphere. Soil Biology \& Biochemistry, 41: 449-457.
Pineros, M.A., Shaff, J.E., Manslank, H.S., Alves, V.M.C. dan Kochian, L.V. 2005. Aluminum Resistance in Maize Cannot be Solely Explained by Root Organic Acid Exudation. Plant Physiology, 137: 231-241.

Prabowo, A.M. 1998. Reaksi Kimia Asam Malat dan Peranannya Sebagai Pencegah Keracunan Aluminium pada Tanah-Tanah Masam. $J$. Agrivita, 20 (1): 27-33.

Ryan, P.R., Delhaize, E. dan Randall, P.J. 1995a. Characterisation of Al-stimulated Efflux of Malate from The Apices of Al-tolerant Wheat Roots. Planta, 196: 103-110.

Ryan, P.R., Delhaize, E. dan Randall, P.J. 1995b. Malate Efflux from Root Apices: Evidence for a General Mechanism of Al-tolerance in Wheat. Aust J Plant Physiol., 22: 531-536.

Ryan, P.R., Delhaize, E. dan Jones, D.L. 2001. Function and Mechanism of Organic Anion Exudation from Plant Roots. Annu Rev Plant Physiol Plant Mol Biol., 52: 527-560.

Sastro, Y., Widianto, D. dan Shiddieq, D. 2006. Sekresi Asam-asam Organik oleh Aspergillus niger YD 17 yang Ditumbuhkan dengan Batuan Fosfat. Biota, XI (3): 167-175.

Sequi, P. dan Aringhieri, R. 1977. Destruction of Organic Matter by Hydrogen Peroxide in the Presence of Pyrophosphate and Its Effect on Soil Specific Surface Area. Soil Sci. Soc. Am. J., 41: 340-342.

Sudiana, I.M. 2004. Isolasi Bakteri Pengakumulasi Poliposfat. Biota, IX (2): 105-113.

van Hees, P.A.W., Jones, D.L. dan Godbold, D.L. 2002. Biodegradation of Low Molecular Weight Organic Acids in Forest Soils. Soil Biology and Biochemistry, 34: 1261-1272.

van Hees, P.A.W., Jones, D.L., Jentschke, G. dan Godbold, D.L. 2005. Organic Acid Concentrations in Soil Solution: Effects of Young Coniferous Trees and Ectomycorrhizal Fungi. Soil Biology \& Biochemistry, 37: 771-776.

van Kessel, C., Nitschelm, J., Horwath, W.R., Harris, D., Walley, F., Luscher, A. dan Hartwig, U. 2000. Carbon-13 Input and Turn Over in a Pasture Soil Exposed to Long-term Elevated Atmospheric $\mathrm{CO}_{2}$. Global Change Biol., 6: 123-135.

Walker, T.S., Bais, H.P., Grotewold, E. dan Vivanco, J.M. 2003. Root Exudation and Rhizosphere Biology. Plant Physiology, 132: 44-51.

Wenzl, P., Mancilla, L.I., Mayer, J.E., Albert, R. dan Rao, I.M. 2003. Simulating Infertile Acid Soils with Nutrient Solutions: The Effects on Brachiaria Species. Soil Sci. Soc. Am. J., 67: 1457-1469. 
Wenzl, P., Arango, A., Chaves, A.L., Buitrago, M.E., Patino, G.M., Miles, J. dan Rao, I.M. 2006. A Greenhouse Method to Screen Brachiaria grass Genotypes for Aluminum Resistance and Root Vigor. Crop Sci., 46: 968-973.

Zhang, X.G., Alter, D., Jessop, R.S. dan Ellison, F. 1998. Exudation of organic acids from roots of triticale. Proceedings of the Australian Agronomy Conference, Australian Society of Agronomy. http://www.regional.org.au/au/. 09/13/2007.

Zhang, X.G., Jessop, R.S. dan Alter, D. 2003. Organic Acid Exudation Associated with Aluminium Stress Tolerance in Triticale and Wheat. Australian J. of Agricultural Research, 54: 979-985. 